\title{
Invited review: mesenchymal progenitor cells in intramuscular connective tissue development
}

\author{
Z. G. Miao ${ }^{1,2 a}$, L. P. Zhang ${ }^{2,3 a}$, X. Fu' ${ }^{2}$, Q. Y. Yang ${ }^{2}$, M. J. Zhu ${ }^{4}$, M. V. Dodson ${ }^{2}$ and M. Du ${ }^{2 \dagger}$ \\ ${ }^{1}$ School of Animal Sciences, Henan Institute of Science and Technology, Xinxiang 453003, China; ${ }^{2}$ Department of Animal Sciences, Washington State University, \\ Pullman, WA 99164, USA; ${ }^{3}$ Institute of Animal Science, Chinese Academy of Agricultural Sciences, Beijing 100193, China; ${ }^{4}$ School of Food Science, Washington State \\ University, Pullman, WA 99164, USA
}

(Received 17 March 2015; Accepted 23 July 2015; First published online 9 September 2015)

\begin{abstract}
The abundance and cross-linking of intramuscular connective tissue contributes to the background toughness of meat, and is thus undesirable. Connective tissue is mainly synthesized by intramuscular fibroblasts. Myocytes, adipocytes and fibroblasts are derived from a common pool of progenitor cells during the early embryonic development. It appears that multipotent mesenchymal stem cells first diverge into either myogenic or non-myogenic lineages; non-myogenic mesenchymal progenitors then develop into the stromal-vascular fraction of skeletal muscle wherein adipocytes, fibroblasts and derived mesenchymal progenitors reside. Because non-myogenic mesenchymal progenitors mainly undergo adipogenic or fibrogenic differentiation during muscle development, strengthening progenitor proliferation enhances the potential for both intramuscular adipogenesis and fibrogenesis, leading to the elevation of both marbling and connective tissue content in the resulting meat product. Furthermore, given the bipotent developmental potential of progenitor cells, enhancing their conversion to adipogenesis reduces fibrogenesis, which likely results in the overall improvement of marbling (more intramuscular adipocytes) and tenderness (less connective tissue) of meat. Fibrogenesis is mainly regulated by the transforming growth factor (TGF) $\beta$ signaling pathway and its regulatory cascade. In addition, extracellular matrix, a part of the intramuscular connective tissue, provides a niche environment for regulating myogenic differentiation of satellite cells and muscle growth. Despite rapid progress, many questions remain in the role of extracellular matrix on muscle development, and factors determining the early differentiation of myogenic, adipogenic and fibrogenic cells, which warrant further studies.
\end{abstract}

Keywords: fibrogenesis, intramuscular connective tissue, meat, progenitor cells, muscle

\section{Implications}

Intramuscular connective tissue contributes to the background toughness of meat, which is mainly synthesized by intramuscular fibroblasts. Recent studies show that adipocytes and fibroblasts are derived from a common pool of mesenchymal progenitor cells during the early embryonic development. Due to the bipotent developmental potential of these progenitor cells, enhancing their conversion to adipogenesis reduces fibrogenesis, which provides an opportunity to improve marbling and tenderness of meat, thus the overall palatability.

\section{Introduction}

Meat quality is determined by flavor, tenderness, juiciness, color, nutritional value and others. Tender meat, which

\footnotetext{
${ }^{a}$ These authors have equal contributions to this reviewer paper.

† E-mail: min.du@wsu.edu
}

contains more intramuscular fat and less connective tissue is demanded by consumers. Meat tenderness is determined by both the myofibrillar effects and the presence and crosslinking of connective tissue. Myofibrillar contribution to toughness can be partially addressed by aging carcasses, which results in the fragmentation of myofibrils primarily due to proteolysis by calpains (Koohmaraie and Geesink, 2006). On the other hand, postmortem aging is ineffective in improving the tenderness of a meat with high collagen content, due to the resistance of collagen to proteolysis. Thus, meat toughness due to connective tissue is called the 'background toughness' of meat (Nishimura, 2010). Consistently, the longissimus muscle in beef cattle contains low collagen and is tenderer while beef from limb muscles possesses higher collagen content and is tougher (McCormick, 1999; Dubost et al., 2013a). In addition, the cross-linking of collagen has even greater influence on meat toughness (McCormick, 1994). Because during 
cooking, collagen is gelatinized, which is hampered due to the presence of cross-linking, contributing to the toughness of meat from old animals (Dubost et al., 2013b). The detailed effects of connective tissue structure, collagen cross-linking, and their impacts on meat tenderness have been previous reviewed (Purslow, 2014).

Intramuscular connective tissue is mainly derived from fibroblasts, which are generated through fibrogenesis, a process referring to the generation of fibroblasts and their synthesis of proteins and other components composing the connective tissue. Fibrogenesis is active during the whole life of animals, particularly during the early developmental stage in utero; connective tissues synthesized inside fetal muscle form primordial perimysium and epimysium of muscle bundles at late gestation (Du et al., 2010). In humans, fibrosis refers to a state of excessive deposition of collagen and other extracellular matrix proteins, which is often elicited by a pathological condition and becomes noticeable during the recovery period (Liu and Pravia, 2010). Lysyl oxidase is a rate limiting enzyme catalyzing cross-linking of collagen fibrils (Borg et al., 1985; Huang et al., 2012b). Available studies demonstrated that the content and cross-linking of collagen are frequently correlated to each other, but the turnover of collagen reduces cross-linking (Archile-Contreras et al., 2010), a process increasing tenderness (Hill, 1967; Archile-Contreras et al., 2011; Purslow et al., 2012).

Intramuscular fat is considered part of the intramuscular connective tissue, and intramuscular adipogenesis is inseparable from fibrogenesis due to closely related developmental origins. However, knowledge regarding regulatory mechanisms, or specific and effective manipulations to augment progenitor cell differentiation to a particular lineage, such as adipogenesis, remains poorly defined. The intent of this review is to provide an overview of current knowledge regarding intramuscular collagen deposition and associated marbling development, and discuss possible mechanisms regulating mesenchymal progenitor cell differentiation focusing on fibrogenesis, and their impacts on muscle growth and meat quality.

\section{Intramuscular connective tissue structure}

\section{Organization of intramuscular connective tissue}

All connective tissues (cartilage, bone, blood and interstitial tissue) possess three common components: cells, fibers and ground substance. Extracellular matrix tissue refers to a major portion of intramuscular connective tissues surrounding muscle fibers and other cells, which is composed of collagen, elastin, fibronectin, proteoglycans, and other ground substance components (Purslow, 2014). Embedded in extracellular matrix and connective tissue, there are abundant fibroblasts, adipocytes, immune cells, preadipocytes, mesenchymal progenitor cells, and other stromal vascular cells. Connective tissue and associated proteins organize muscle structure, connect muscle fibers to the bone for locomotion, and also mediate muscle growth and development (Sanes, 2003; Jenniskens et al., 2006). The connective tissues surrounding each muscle fiber, termed endomysium, comprised two layers. The inner layer, termed basal lamina, is a 50 to $100 \mathrm{~nm}$ thick layer surrounding the sarcolemma, which connects muscle fibers to extracellular niche environment and regulates myogenesis (Wang et al., 2014), and muscle growth (Velleman, 1999). Outside of the endomysium, a thin layer of connective tissue, which integrates into thicker layers between muscle bundles, termed perimysium, and surrounding each muscle, termed epimysium. These connective tissues connect muscle fibers and bundles together, and maintain muscle integrity. Intramuscular adipocytes, blood vessels and nerves are integrated into the connective tissue matrix of the muscle.

\section{Connective tissue structure}

Collagen is the major component of connective tissue. There are a number of different types of collagens, which are derived from more than 30 genes (Myllyharju and Kivirikko, 2004; Veit et al., 2006; Soderhall et al., 2007). However, in muscle, types I and III collagen are dominant (Light et al., 1985). The ratio of type I to III may be altered depending on muscle types, locations and animal ages (Listrat et al., 1999). In mature bovine muscles, type I collagen is more abundant in perimysium, but type III collagen levels are enriched in the endomysium (Mayne and Sanderson, 1985). In rats, during aging, the proportion of type I collagen increased, while type III collagen decreased (Kovanen and Suominen, 1989); an increase in type I collagen was also observed in the intramuscular connective tissue of beef cattle at around 6 months of age (Listrat et al., 1999). Up to now, most studies about connective tissue in muscle have been focused on types I and III collagens (Sato et al., 1994; Sato et al., 1997; Duarte et al., 2013).

Each collagen molecule contains three helical polypeptide chains, which are interwined. At both ends, however, nonhelical regions termed telopeptide regions are found. Lysyl oxidase is a critical enzyme regulating collagen cross-linking (Siegel and Fu, 1976; Siegel et al., 1976). Lysyl oxidase oxidizes lysine or hydroxylysine in the non-helical portions of collagen molecules to aldehydes, which then react with neighboring collagen molecules to form divalent bonds. Therefore, the presence of lysine and hydroxylysine in the non-helical regions is critical in determining cross-linking development (Robins, 2007). The degree of collagen crosslinking differs in animals of different breeds. In our study with Wagyu and Angus cattle, we found that the collagen content and cross-linking are higher in Wagyu, which correlates with less soluble collagen content (Duarte et al., 2013). We also observed that early nutrition affects collagen content and cross-linking in sheep (Huang et al., 2010). In addition, collagens of different muscle types have various degrees of cross-linking, with the collagen in longissimus muscle having less cross-linking than biceps muscle (Dubost et al., 2013a), correlated with meat tenderness. Collagen cross-linking is a slow process, which increases as animals age, and the high degree of cross-linking is one of the primary reasons for the toughness of meat from old animals. On the other hand, collagens undergo consistent turnover, 
albeit slower than other proteins. Because newly synthesized collagens do not contain cross-linking, factors that enhance collagen turnover, reduce cross-linking and improve meat tenderness (Purslow, 2014). Indeed, cross-linking was reduced and soluble collagen content was raised in compensatory growing pigs (Kristensen et al., 2002). Collagen turnover, or remodeling, is regulated by metalloproteinases (Woessner, 1991; Murphy, 2010). The expression of metalloproteinases and their inhibitors, the tissue inhibitors of metalloproteinases, are regulated by a number of factors (Clark et al., 2008), such as inflammation and oxidative stress, which affect cross-linking and meat tenderness (Purslow, 2014).

\section{Development of connective tissue}

Fibrogenic cells and adipocytes share common progenitor cells

During early skeletal muscle development, mesenchymal stem cells first diverge to either myogenic or non-myogenic lineages. Myogenic progenitors further develop into muscle fibers and satellite cells, whereas non-myogenic progenitor cells develop into the stromal-vascular fraction of mature skeletal muscle in which resides adipocytes, fibroblasts and resident mesenchymal progenitor cells (Du et al., 2013). These non-myogenic progenitors have adipogenic and fibrogenic capacity, as well as osteogenic and chondrogenic potential (Joe et al., 2010; Wosczyna et al., 2012). These cells are mainly located in the stromal-vascular fraction of skeletal muscle and are distinct from satellite cells (Joe et al., 2010; Uezumi et al., 2010). Platelet-derived growth factor receptor $\alpha$ (PDGFR $\alpha)$ is a reliable marker for separating these cells, and $\mathrm{Sca}-1^{+} \mathrm{CD} 34^{+}$appears to label the same cell population (Joe et al., 2010; Uezumi et al., 2010, 2011 and 2014).

The notion that mesenchymal progenitor cells as the common sources of adipogenic and fibrogenic cells are further proven by the co-expression of PDGFR $\alpha$ with fibrogenic markers (Murphy et al., 2011), or PDGFR $\alpha$ with adipogenic markers (Yang et al., 2013). Transcription factor 4 (TCF4), also known as transcription factor 7-like 2 (Tcf7/2), was first found to be related with limb development by interacting with Wnt signaling pathway (Cho and Dressler, 1998). Subsequent studies demonstrate TCF4 as a fibrogenic marker (Kardon et al., 2003; Mathew et al., 2011). A portion of TCF4 ${ }^{+}$fibroblasts also express PDGFR $\alpha$ (Murphy et al., 2011), showing the intrinsic relationship between mesenchymal progenitor cells and TCF4 ${ }^{+}$fibroblasts. Similarly, in our previous studies, we detected the co-expression of PDGFR $\alpha$ with ZFP423, a marker of adipogenic commitment (Yang et al., 2013). The lack of TCF4 + and ZFP423 co-expressed cells show the divergence of the fibrogenic and adipogenic lineages during progenitor differentiation.

\section{Mechanisms regulating fibrogenesis}

Transforming growth factor (TGF)- $\beta$ is the most important profibrogenic cytokine (Liu and Pravia, 2010). TGF superfamily contains several structurally related subfamilies, including TGF- $\beta$, bone morphogenetic proteins and activin. Three isoforms of TGF- $\beta$ have been identified, which are TGF- $\beta 1$, TGF- $\beta 2$ and TGF- $\beta 3$. The TGF- $\beta 1$ isoform is primarily expressed in endothelial cells, fibroblasts, hematopoietic cells and smooth muscle cells; TGF- $\beta 2$ mainly exists in epithelial cells and neurons; and TGF- $\beta 3$ is specifically expressed in mesenchymal cells (Ghosh et al., 2005). All TGF- $\beta$ isoforms activate down-stream SMAD signaling (Attisano and Wrana, 1996; Letterio and Roberts, 1998). The SMAD family contains five receptor-regulated SMAD (R-SMAD 1, 2, 3, 5 and 8), a common SMAD (Co-SMAD 4), and two inhibitor SMAD (I-SMAD 6 and 7) (Moustakas et al., 2001). The ligand, TGF- $\beta$, first binds to TGF- $\beta$ receptor II (T $\beta R$ II), which then recruits and activates T $\beta R$ I. Then SMAD2 and SMAD3 are phosphorylated and subsequently bind to SMAD4 (Suwanabol et al., 2011), and the resulting SMAD complex is translocated into the nucleus where it binds to SMAD-specific binding elements of target genes, thereby activating the expression of fibrogenic genes including procollagen and enzymes catalyzing collagen cross-linking (Massague and Chen, 2000). As an anti-inflammatory cytokine, TGF- $\beta$ signaling is enhanced by inflammation (Bhatnagar et al., 2010; Voloshenyuk et al., 2011), while inhibited by anti-inflammatory factors (Wang et al., 2012).

Connective tissue growth factor (CTGF) is a crucial switch to regulate downstream fibrotic progress (Grotendorst, 1997; Leask et al., 2004). CTGF is a member of CCN family, which are cysteine rich proteins. CTGF gene expression is induced by TGF- $\beta$-activated Smad3 binding to its promoter region (Denton and Abraham, 2001; Holmes et al., 2001). Then, CTGF directly stimulates fibroblast proliferation and ECM deposition (Shi-Wen et al., 2008; Morales et al., 2011). Wingless/int (Wnt) signaling pathway plays a crucial role in cell fate commitment (Dorsky et al., 1998; Ross et al., 2000), and synergizes with TGF- $\beta$ signaling to promote connective tissue synthesis and fibrosis (Brack et al., 2007; Zhou et al., 2012; Cisternas et al., 2014).

Ski/sno family includes ski and sno, which has four distinct isoforms SnoN, SnoN2, SnoA and Snol (Nomura et al., 1989; Pearson-White, 1993; Pelzer et al., 1996). Ski/sno family acts as negative regulators of TGF- $\beta 1$ pathway by functioning on the downstream signal molecules R-smad/Co-smad complex (Luo, 2004; Deheuninck and Luo, 2009; Jahchan and Luo, 2010), thus reducing connective tissue deposition.

MicroRNAs regulate cell differentiation through inhibiting the expression of target genes. MiR-101 a inhibits fibrosis by targeting the T $\beta R \mathrm{I}$ on cardiac fibroblasts (Zhao et al., 2015). High glucose increases the activity of transcriptional co-activator p300, which subsequently enhances the activity of $\operatorname{TGF} \beta$ pathway by inducing Smad2 acetylation (Bugyei-Twum et al., 2014). Besides, ERK5, one of the MAPK family members, is a critical regulator in TGF$\beta 1$-induced lung fibrosis by enhancing Smad3 acetylation (Kim et al., 2013). A number of cytokines and growth factors, which are involved in the regulation of fibrogenesis are listed in Table 1. 
Miao, Zhang, Fu, Yang, Zhu, Dodson and Du

Table 1 Factors enhancing and decreasing intramuscular fibrogenesis

\begin{tabular}{|c|c|c|c|}
\hline Name & Fibrogenesis & Summary & References \\
\hline $\operatorname{TGF} \beta$ & Up & A key pathway driving fibrogenesis through Smad signaling & $\begin{array}{l}\text { Poncelet and Schnaper } \\
\text { (2001); Liu and Pravia } \\
\text { (2010) }\end{array}$ \\
\hline $\begin{array}{l}\text { Inflammatory } \\
\text { cytokines }\end{array}$ & Up & $\begin{array}{l}\text { Inflammatory cytokines, such as TNF } \alpha, \text { IL-1 } \alpha, \text { IL- } 1 \beta \text { and others, promote fibrogenesis } \\
\text { through enhancing } \operatorname{TGF} \beta \text { expression }\end{array}$ & $\begin{array}{l}\text { Bhatnagar et al. (2010); } \\
\text { Voloshenyuk et al. (2011) }\end{array}$ \\
\hline Wnts & Up & Wnt signaling synergizes with $\operatorname{TGF} \beta$ signaling to promote fibrogenesis & $\begin{array}{l}\text { Zhou et al. (2012); Cisternas } \\
\text { et al. (2014) }\end{array}$ \\
\hline FGF-2 & Up & Promotes the proliferation of fibroblasts and fibro/adipogenic progenitor cells & $\begin{array}{l}\text { lannaccone et al. (1995); } \\
\quad \text { Virag et al.( 2007) }\end{array}$ \\
\hline CTGF & Up & Promotes fibroblast proliferation and fibrogenic protein deposition & $\begin{array}{l}\text { Shi-Wen et al. (2008); } \\
\quad \text { Morales et al. (2011) }\end{array}$ \\
\hline PDGF & Up & Stimulates proliferation of fibroblasts and enhances TGF $\beta$ signaling & $\begin{array}{l}\text { Zhao et al., (2013); } \\
\text { Makihara et al. (2015) }\end{array}$ \\
\hline $\begin{array}{l}\text { Anti- } \\
\text { inflammatory } \\
\text { factors }\end{array}$ & Down & $\begin{array}{l}\text { Anti-inflammatory factors down-regulate TGF } \beta \text { signaling through inhibiting } \\
\text { inflammation }\end{array}$ & Wang et al. (2012) \\
\hline Ski/SnoN & Down & $\begin{array}{l}\text { Ski/SnoN family of oncoproteins bind to Smad proteins to inhibit the expression of TGF } \beta \\
\text { responsive genes, including fibrogenic genes }\end{array}$ & Liu et al. (2001) \\
\hline Zfp423 & Down & $\begin{array}{l}\text { Zfp423 promotes adipogenic differentiation of adipo/fibrogenic progenitor cells, which } \\
\text { reduce fibrogenesis }\end{array}$ & Huang et al. (2012a) \\
\hline MMPs & Down & Catalyze connective tissue degradation and promote extracellular tissue remodeling & Balcerzak et al. (2001) \\
\hline TIMPs & Up & Inhibits MMPs and connective tissue remodeling & Balcerzak et al. (2001) \\
\hline
\end{tabular}

$\mathrm{CTGF}=$ connective tissue growth factor; FGF- $2=$ basic fibroblast growth factor; MMPs = matrix metablloproteinase; PDGF = platelet-derived growth factor; $\operatorname{TGF} \beta=$ tumor growth factor $\beta$; TIMP = tissue inhibitor of metalloproteinase; Wnts = wingless and ints.

Antagonistic effects of adipogenesis on fibrogenesis

Because fibrogenesis and adipogenesis are considered as a competitive process, enhancing adipogenesis reduces fibrogenesis. Adipogenesis can be separated into two steps, the commitment of progenitors to preadipocytes, and the differentiation of preadipocytes to mature adipocytes. Quite recently, Zfp423 was identified as the key regulator committing progenitors to preadipocytes; in addition, Zfp423 promotes the expression of peroxisome proliferator-activated

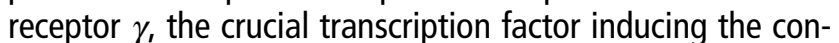
version of preadipocytes to adipocytes (Gupta et al., 2010; Gupta et al., 2012). Importantly, in cattle mesenchymal progenitor cells, the expression of Zfp423 is negatively correlated with TGF- $\beta 1$ expression, indicating the mutual exclusion of adipogenesis and fibrogenesis (Huang et al., 2012a).

\section{Connective tissue and muscle development}

Satellite cells are critical for muscle growth and regeneration. They are wedged between the basal lamina and the plasma membrane (sarcolemma) of skeletal muscle fibers. Extracellular matrix together with growth factors and cytokines sequestered inside and those secreted by interstitial cells, forms the niche environment needed for satellite cell quiescence, activation, migration, myogenic differentiation and muscle development (Rhoads et al., 2009; Dodson et al., 2010; Murphy et al., 2011; Urciuolo et al., 2013).
Muscle regeneration involves extensive proliferation and myogenic differentiation of satellite cells. Shortly after muscle injury, both satellite cells and non-myogenic progenitor cells are activated and proliferate; non-myogenic progenitor cells stimulate satellite cell proliferation and facilitate muscle regeneration (Joe et al., 2010; Murphy et al., 2011). In addition, intramuscular fibroblasts particularly promote slow myogenesis, thus affecting muscle fiber type composition and overall maturation during muscle development (Mathew et al., 2011). Extracellular component, collagen $\mathrm{VI}$, regulates satellite cell self-renewal and differentiation (Urciuolo et al., 2013). Besides, other components of extracellular matrix, such as proteoglycan, regulate proliferation and differentiation of satellite cells (Zhang et al., 2007). Decorin, a small leucine-rich proteoglycan, $\operatorname{traps} \operatorname{TGF} \beta$ to regulate satellite cell activation and muscle growth (Li et al., 2006 and 2008).

Extracellular matrix also interacts with a number of growth factors, including $\operatorname{TGF} \beta$, hepatocyte growth factor, fibroblast growth factor 2, myostatin and others to either promote or inhibit muscle growth (Yamaguchi et al., 1990; Rapraeger et al., 1991; Allen et al., 1995; Miura et al., 2006; Kishioka et al., 2008). Table 2 lists selected growth factors known to interact with extracellular matrix and regulate muscle growth.

\section{Conclusions}

Intramuscular connective tissue regulates muscle growth and development, and also is the site for intramuscular fat (marbling) deposition. The abundance and cross-linking of 
Progenitor cells and connective tissue

Table 2 Growth factors associated with extracellular matrix and associated cells to regulate activation of satellite cells

\begin{tabular}{|c|c|c|}
\hline Name & Summary & References \\
\hline $\mathrm{HGF} / \mathrm{SF}$ & $\begin{array}{l}\text { Binds to ECM. It is released during ECM degradation to promote satellite cell } \\
\text { activation and proliferation }\end{array}$ & Poncelet and Schnaper (2001), Liu and Pravia (2010) \\
\hline FGF-2 & Is secreted by fibroblasts, which stimulates satellite cell proliferation & $\begin{array}{l}\text { Sheehan and Allen, (1999), Velleman (2007), Zhang } \\
\text { et al. (2008) }\end{array}$ \\
\hline $\begin{array}{l}\text { IGF-1, } \\
\text { IGF-2 }\end{array}$ & Promotes satellite cell proliferation and muscle anabolism & McFarland et al. (1993), Haugk et al. (1995) \\
\hline PDGF-BB & Promotes satellite cell proliferation & Doumit et al. (1993) \\
\hline TGF $\beta$ & Antagonizes FGF-2 to inhibit satellite cell proliferation & Shi-Wen et al. (2008), Morales et al. (2011) \\
\hline SDF-1 & Promotes satellite cell activation, proliferation and myogenesis & Brzoska et al. (2012) \\
\hline EGF & Promotes satellite cell proliferation and protein synthesis & Roe et al. (1989), Mau et al. (2008) \\
\hline
\end{tabular}

$\mathrm{EGF}=$ epithelial growth factor; FGF-2 = fibroblast growth factor-2; HGF/SF = hepatocyte growth factor/scatter factor; IGF $=$ insulin growth factor; PDGF-BB $=$ platelet-derived growth factor-BB; SDF-1 = stromal-derived factor-1; TGF $\beta=$ transforming growth factor $\beta$.

intramuscular connective tissue contribute to the background toughness of meat. Connective tissue is mainly synthesized by intramuscular fibroblasts. Non-myogenic mesenchymal progenitor cells are the common source of fibroblasts and adipocytes. Strengthening progenitor cell formation and proliferation enhances both intramuscular adipogenesis and fibrogenesis, while enhancing progenitor differentiation to adipogenesis reduces fibrogenesis, resulting in the overall improvement of marbling and tenderness of meat. Fibrogenesis is mainly regulated by the $\operatorname{TGF} \beta$ signaling pathway, and a number of factors affect connective tissue deposition via altering $\operatorname{TGF} \beta$ signaling. Extracellular matrix, a part of the intramuscular connective tissue, provides a niche environment to regulate myogenic differentiation of satellite cells and muscle growth. Despite rapid progress in our understanding of mechanisms regulating fibrogenesis, many questions remain on the synthesis of intramuscular connective tissue and the role of extracellular matrix in muscle development, which warrants further studies.

\section{Acknowledgements}

This project was supported by Agriculture and Food Research Initiative Competitive Grant No. 2015-67015-23219 from the USDA National Institute of Food and Agriculture, and NIH R01 HD067449.

\section{References}

Allen RE, Sheehan SM, Taylor RG, Kendall TL and Rice GM 1995. Hepatocyte growth factor activates quiescent skeletal muscle satellite cells in vitro. Journal of Cellular Physiology 165, 307-312.

Archile-Contreras AC, Cha MC, Mandell IB, Miller SP and Purslow PP 2011. Vitamins $E$ and $C$ may increase collagen turnover by intramuscular fibroblasts. Potential for improved meat quality. Journal of Agricultural and Food Chemistry $59,608-614$.

Archile-Contreras AC, Mandell IB and Purslow PP 2010. Disparity of dietary effects on collagen characteristics and toughness between two beef muscles. Meat Science 86, 491-497.

Attisano $L$ and Wrana JL 1996. Signal transduction by members of the transforming growth factor-beta superfamily. Cytokine \& Growth Factor Reviews 7 327-339.
Balcerzak D, Querengesser L, Dixon WT and Baracos VE 2001. Coordinate expression of matrix-degrading proteinases and their activators and inhibitors in bovine skeletal muscle. Journal of Animal Science 79, 94-107.

Bhatnagar S, Panguluri SK, Gupta SK, Dahiya S, Lundy RF and Kumar A 2010. Tumor necrosis factor-alpha regulates distinct molecular pathways and gene networks in cultured skeletal muscle cells. PLoS One 5, e13262.

Borg TK, Klevay LM, Gay RE, Siegel R and Bergin ME 1985. Alteration of the connective tissue network of striated muscle in copper deficient rats. Journal of Molecular and Cellular Cardiology 17, 1173-1183.

Brack AS, Conboy MJ, Roy S, Lee M, Kuo CJ, Keller C and Rando TA 2007. Increased Wnt signaling during aging alters muscle stem cell fate and increases fibrosis. Science 317, 807-810.

Brzoska E, Kowalewska M, Markowska-Zagrajek A, Kowalski K, Archacka K, Zimowska M, Grabowska I, Czerwinska AM, Czarnecka-Gora M, Streminska W, Janczyk-llach K and Ciemerych MA 2012. Sdf-1 (CXCL12) improves skeletal muscle regeneration via the mobilisation of $\mathrm{Cxcr} 4$ and CD34 expressing cells. Biology of the Cell 104, 722-737.

Bugyei-Twum A, Advani A, Advani SL, Zhang Y, Thai K, Kelly DJ and Connelly KA 2014. High glucose induces Smad activation via the transcriptional coregulator p300 and contributes to cardiac fibrosis and hypertrophy. Cardiovascular Diabetology 13, 89.

Cho EA and Dressler GR 1998. TCF-4 binds beta-catenin and is expressed in distinct regions of the embryonic brain and limbs. Mechanisms of Development 77, 9-18.

Cisternas P, Vio CP and Inestrosa NC 2014. Role of Wnt signaling in tissue fibrosis, lessons from skeletal muscle and kidney. Current Molecular Medicine 14, 510-522.

Clark IM, Swingler TE, Sampieri CL and Edwards DR 2008. The regulation of matrix metalloproteinases and their inhibitors. The International Journal of Biochemistry \& Cell Biology 40, 1362-1378.

Deheuninck J and Luo K 2009. Ski and SnoN, potent negative regulators of TGF-beta signaling. Cell Research 19, 47-57.

Denton CP and Abraham DJ 2001. Transforming growth factor-beta and connective tissue growth factor: key cytokines in scleroderma pathogenesis. Current Opinion in Rheumatology 13, 505-511.

Dodson MV, Hausman GJ, Guan L, Du M, Rasmussen TP, Poulos SP, Mir $P$, Bergen WG, Fernyhough ME, McFarland DC, Rhoads RP, Soret B, Reecy JM, Velleman SG and Jiang Z 2010. Skeletal muscle stem cells from animals I. Basic cell biology. International Journal of Biological Science 6, 465-474.

Dorsky RI, Moon RT and Raible DW 1998. Control of neural crest cell fate by the Wnt signalling pathway. Nature 396, 370-373.

Doumit ME, Cook DR and Merkel RA 1993. Fibroblast growth factor, epidermal growth factor, insulin-like growth factors, and platelet-derived growth factor-BB stimulate proliferation of clonally derived porcine myogenic satellite cells. Journal of Cell Physiology 157, 326-332.

Du M, Huang Y, Das AK, Yang Q, Duarte MS, Dodson MV and Zhu M-J 2013. Meat Science And Muscle Biology Symposium: manipulating mesenchymal 
progenitor cell differentiation to optimize performance and carcass value of beef cattle. Journal of Animal Science 91, 1419-1427.

Du M, Yan X, Tong JF, Zhao JX and Zhu MJ 2010. Maternal obesity, inflammation, and fetal skeletal muscle development. Biology of Reproduction 82, 4-12. Duarte MS, Paulino PV, Das AK, Wei S, Serao NV, Fu X, Harris SM, Dodson MV and Du M 2013. Enhancement of adipogenesis and fibrogenesis in skeletal muscle of Wagyu compared with Angus cattle. Journal of Animal Science 91, 2938-2946.

Dubost A, Micol D, Meunier B, Lethias C and Listrat A 2013a. Relationships between structural characteristics of bovine intramuscular connective tissue assessed by image analysis and collagen and proteoglycan content. Meat Science 93, 378-386.

Dubost A, Micol D, Picard B, Lethias C, Andueza D, Bauchart D and Listrat A 2013b. Structural and biochemical characteristics of bovine intramuscular connective tissue and beef quality. Meat Science 95, 555-561.

Ghosh J, Murphy MO, Turner N, Khwaja N, Halka A, Kielty CM and Walker MG 2005. The role of transforming growth factor beta1 in the vascular system. Cardiovascular Pathology 14, 28-36.

Grotendorst GR 1997. Connective tissue growth factor: a mediator of TGF-beta action on fibroblasts. Cytokine \& Growth Factor Reviews 8, 171-179.

Gupta RK, Arany Z, Seale P, Mepani RJ, Ye L, Conroe HM, Roby YA, Kulaga H, Reed RR and Spiegelman BM 2010. Transcriptional control of preadipocyte determination by Zfp423. Nature 464, 619-623.

Gupta RK, Mepani RJ, Kleiner S, Lo JC, Khandekar MJ, Cohen P, Frontini A, Bhowmick DC, Ye L, Cinti S and Spiegelman BM 2012. Zfp423 expression identifies committed preadipocytes and localizes to adipose endothelial and perivascular cells. Cell Metabolism 15, 230-239.

Haugk KL, Roeder RA, Garber MJ and Schelling GT 1995. Regulation of muscle cell proliferation by extracts from crushed muscle. Journal of Animal Science 73, 1972-1981.

Hill F 1967. The chemical composition of muscles from steers which experienced compensatory growth. Journal of the Science of Food Agriculture 18, 164-166.

Holmes A, Abraham DJ, Sa S, Shiwen X, Black CM and Leask A 2001. CTGF and SMADs, maintenance of scleroderma phenotype is independent of SMAD signaling. Journal of Biological Chemistry 276, 10594-10601.

Huang Y, Das AK, Yang OY, Zhu MJ and Du M 2012a. Zfp423 promotes adipogenic differentiation of bovine stromal vascular cells. PLoS One 7, e47496.

Huang Y, Yan X, Zhu MJ, McCormick RJ, Ford SP, Nathanielsz PW and Du M 2010. Enhanced transforming growth factor-beta signaling and fibrogenesis in ovine fetal skeletal muscle of obese dams at late gestation. American Journal of Physiology - Endocrinology and Metabolism 298, E1254-E1260.

Huang Y, Zhao JX, Yan X, Zhu MJ, Long NM, McCormick RJ, Ford SP, Nathanielsz PW and Du M 2012b. Maternal obesity enhances collagen accumulation and cross-linking in skeletal muscle of ovine offspring. PLoS One 7, e31691.

lannaccone S, Quattrini A, Smirne S, Sessa M, de Rino F, Ferini-Strambi $L$ and Nemni R 1995. Connective tissue proliferation and growth factors in animal models of Duchenne muscular dystrophy. Journal of the Neurological Sciences 128, 36-44.

Jahchan NS and Luo K 2010. SnoN in mammalian development, function and diseases. Current Opinion in Pharmacology 10, 670-675.

Jenniskens YM, Koevoet W, de Bart ACW, Weinans $H$, Jahr $H$, Verhaar JAN DeGroot J and van Osch GJVM 2006. Biochemical and functional modulation of the cartilage collagen network by IGF1, TGF beta 2 and FGF2. Osteoarthritis and Cartilage 14, 1136-1146.

Joe AW, Yi L, Natarajan A, Le Grand F, So L, Wang J, Rudnicki MA and Rossi FM 2010. Muscle injury activates resident fibro/adipogenic progenitors that facilitate myogenesis. Nature Cell Biology 12, 153-163.

Kardon G, Harfe BD and Tabin CJ 2003. A Tcf4-positive mesodermal population provides a prepattern for vertebrate limb muscle patterning. Developmental Cell 5, 937-944.

Kim S, Lim JH and Woo CH 2013. ERK5 inhibition ameliorates pulmonary fibrosis via regulating Smad3 acetylation. American Journal of Pathology 183, 1758-1768. Kishioka Y, Thomas M, Wakamatsu Ji, Hattori A, Sharma M, Kambadur R and Nishimura T 2008. Decorin enhances the proliferation and differentiation of myogenic cells through suppressing myostatin activity. Journal of Cellular Physiology 215, 856-867.

Koohmaraie M and Geesink GH 2006. Contribution of postmortem muscle biochemistry to the delivery of consistent meat quality with particular focus on the calpain system. Meat Science 74, 34-43.
Kovanen V and Suominen $\mathrm{H}$ 1989. Age- and training-related changes in the collagen metabolism of rat skeletal muscle. European Journal of Applied Physiology and Occupational Physiology 58, 765-771.

Kristensen L, Therkildsen M, Riis B, Sørensen MT, Oksbjerg N, Purslow P and Ertbjerg P 2002. Dietary-induced changes of muscle growth rate in pigs: effects on in vivo and postmortem muscle proteolysis and meat quality. Journal of Animal Science 80, 2862-2871.

Leask A, Denton CP and Abraham DJ 2004. Insights into the molecular mechanism of chronic fibrosis: the role of connective tissue growth factor in scleroderma. Journal of Investigative Dermatology 122, 1-6.

Letterio JJ and Roberts AB 1998. Regulation of immune responses by TGF-beta. Annual Review Immunology 16, 137-161.

Li X, McFarland DC and Velleman SG 2006. Effect of transforming growth factorbeta on decorin and beta1 integrin expression during muscle development in chickens. Poultry Science 85, 326-332.

Li X, McFarland DC and Velleman SG 2008. Extracellular matrix proteoglycan decorin-mediated myogenic satellite cell responsiveness to transforming growth factor-beta1 during cell proliferation and differentiation Decorin and transforming growth factor-beta1 in satellite cells. Domestic Animal Endocrinology $35,263-273$

Light N, Champion AE, Voyle C and Bailey AJ 1985. The role of epimysial, perimysial and endomysial collagen in determining texture in six bovine muscles. Meat Science 13, 137-149.

Listrat A, Picard B and Geay Y 1999. Age-related changes and location of type I, III, IV, V and VI collagens during development of four foetal skeletal muscles of double-muscled and normal bovine animals. Tissue Cell 31, 17-27.

Liu RM and Pravia KAG 2010. Oxidative stress and glutathione in TGF-betamediated fibrogenesis. Free Radical Biology and Medicine 48, 1-15.

Liu X, Sun Y, Weinberg RA and Lodish HF 2001. Ski/Sno and TGF-beta signaling. Cytokine \& Growth Factor Reviews 12, 1-8.

Luo K 2004. Ski and SnoN: negative regulators of TGF-beta signaling. Current Opinion in Genetics \& Development 14, 65-70.

Makihara N, Arimura K, Ago T, Tachibana M, Nishimura A, Nakamura K, Matsuo R, Wakisaka Y, Kuroda J, Sugimori H, Kamouchi M and Kitazono T 2015. Involvement of platelet-derived growth factor receptor beta in fibrosis through extracellular matrix protein production after ischemic stroke. Experimental Neurology 264, 127-134.

Massague J and Chen YG 2000. Controlling TGF-beta signaling. Genes \& Development 14, 627-644.

Mathew SJ, Hansen JM, Merrell AJ, Murphy MM, Lawson JA, Hutcheson DA Hansen MS, Angus-Hill M and Kardon G 2011. Connective tissue fibroblasts and Tcf4 regulate myogenesis. Development 138, 371-384.

Mau M, Kalbe C, Wollenhaupt K, Nurnberg G and Rehfeldt C 2008. IGF-I- and EGFdependent DNA synthesis of porcine myoblasts is influenced by the dietary isoflavones genistein and daidzein. Domestic Animal Endocrinology 35, 281-289. Mayne R and Sanderson RD 1985. The extracellular matrix of skeletal muscle. Collagen and Related Research 5, 449-468.

McCormick RJ 1994. The flexibility of the collagen compartment of muscle. Meat Science 36, 79-91.

McCormick RJ 1999. Extracellular modifications to muscle collagen: implications for meat quality. Poultry Science 78, 785-791.

McFarland DC, Pesall JE and Gilkerson KK 1993. The influence of growth factors on turkey embryonic myoblasts and satellite cells in vitro. General and Comparative Endocrinology 89, 415-424.

Miura T, Kishioka Y, Wakamatsu J-i, Hattori A, Hennebry A, Berry CJ, Sharma M, Kambadur R and Nishimura T 2006. Decorin binds myostatin and modulates its activity to muscle cells. Biochemical and Biophysical Research Communications 340, 675-680.

Morales MG, Cabello-Verrugio C, Santander C, Cabrera D, Goldschmeding R and Brandan E 2011. CTGF/CCN-2 over-expression can directly induce features of skeletal muscle dystrophy. Journal of Pathology 225, 490-501.

Moustakas A, Souchelnytskyi S and Heldin CH 2001. Smad regulation in TGFbeta signal transduction. Journal of Cell Science 114, 4359-4369.

Murphy G 2010. Fell-Muir Lecture: metalloproteinases: from demolition squad to master regulators. International Journal of Experimental Pathology 91, 303-313.

Murphy MM, Lawson JA, Mathew SJ, Hutcheson DA and Kardon G 2011. Satellite cells, connective tissue fibroblasts and their interactions are crucial for muscle regeneration. Development 138, 3625-3637. 
Myllyharju J and Kivirikko KI 2004. Collagens, modifying enzymes and their mutations in humans, flies and worms. Trends in Genetics 20, 33-43.

Nishimura T 2010. The role of intramuscular connective tissue in meat texture. Animal Science Journal 81, 21-27.

Nomura N, Sasamoto S, Ishii S, Date T, Matsui M and Ishizaki R 1989. Isolation of human CDNA clones of ski and the ski-related gene, sno. Nucleic Acids Research 17, 5489-5500.

Pearson-White S 1993. Snol, a novel alternatively spliced isoform of the ski protooncogene homolog, sno. Nucleic Acids Research 21, 4632-4638.

Pelzer T, Lyons GE, Kim S and Moreadith RW 1996. Cloning and characterization of the murine homolog of the sno proto-oncogene reveals a novel splice variant. Developmental Dynamics 205, 114-125.

Poncelet AC and Schnaper HW 2001. Sp1 and Smad proteins cooperate to mediate transforming growth factor-beta 1-induced alpha 2(I) collagen expression in human glomerular mesangial cells. Journal of Biological Chemistry 276, 6983-6992.

Purslow PP 2014. New developments on the role of intramuscular connective tissue in meat toughness. Annual Review of Food Science and Technology 5, 133-153.

Purslow P, Archile-Contreras A and Cha M 2012. Meat Science And Muscle Biology Symposium: manipulating meat tenderness by increasing the turnover of intramuscular connective tissue. Journal of Animal Science 90, 950-959.

Rapraeger AC, Krufka A and Olwin BB 1991. Requirement of heparan sulfate for bFGF-mediated fibroblast growth and myoblast differentiation. Science 252 1705-1708.

Rhoads RP, Fernyhough ME, Liu X, McFarland DC, Velleman SG, Hausman G and Dodson MV 2009. Extrinsic regulation of domestic animal-derived myogenic satellite cells II. Domestic Animal Endocrinology 36, 111-126.

Robins SP 2007. Biochemistry and functional significance of collagen crosslinking. Biochemical Society Transactions 35, 849-852.

Roe JA, Harper JM and Buttery PJ 1989. Protein metabolism in ovine primary muscle cultures derived from satellite cells - effects of selected peptide hormones and growth factors. Journal of Endocrinology 122, 565-571.

Ross $\mathrm{SE}$, Hemati $\mathrm{N}$, Longo $\mathrm{KA}$, Bennett $\mathrm{CN}$, Lucas $\mathrm{PC}$, Erickson RL and MacDougald OA 2000. Inhibition of adipogenesis by Wnt signaling. Science 289, 950-953.

Sanes JR 2003. The basement membrane/basal lamina of skeletal muscle. Journal of Biological Chemistry 278, 12601-12604.

Sato K, Ando M, Kubota S, Origasa K, Kawase H, Toyohara H, Sakaguchi M, Nakagawa T, Makinodan Y, Ohtsuki K and Kawabata M 1997. Involvement of type $\mathrm{V}$ collagen in softening of fish muscle during short-term chilled storage. Journal of Agricultural and Food Chemistry 45, 343-348.

Sato K, Sakuma A, Ohtsuki K and Kawabata M 1994. Subunit composition of Eel (Anguilla-Japonica) type-V collagen - evidence for existence of a novel 4Th Alpha-4(V) chain. Journal of Agricultural and Food Chemistry 42, 675-678.

Sheehan SM and Allen RE 1999. Skeletal muscle satellite cell proliferation in response to members of the fibroblast growth factor family and hepatocyte growth factor. Journal of Cell Physiology 181, 499-506.

Shi-Wen X, Leask A and Abraham D 2008. Regulation and function of connective tissue growth factor/CCN2 in tissue repair, scarring and fibrosis. Cytokine \& Growth Factor Reviews 19, 133-144.

Siegel RC and Fu JC 1976. Collagen cross-linking. Purification and substrate specificity of lysyl oxidase. Journal of Biological Chemistry 251, 5779-5785.

Siegel RC, Fu JC and Chang Y 1976. Collagen cross-linking: the substrate specificity of lysyl oxidase. Advances in Experimental Medicine and Biology 74, 438-446.

Soderhall C, Marenholz I, Kerscher T, Ruschendorf $F$, Esparza-Gordillo J, Worm M, Gruber C, Mayr G, Albrecht M, Rohde K, Schulz H, Wahn U, Hubner N and Lee YA 2007. Variants in a novel epidermal collagen gene (COL29A1) are associated with atopic dermatitis. PLoS Biology 5, e242.

Suwanabol PA, Kent KC and Liu B 2011. TGF-beta and restenosis revisited: a Smad link. Journal of Surgical Research 167, 287-297.

Uezumi A, Ikemoto-Uezumi M and Tsuchida K 2014. Roles of nonmyogenic mesenchymal progenitors in pathogenesis and regeneration of skeletal muscle. Frontiers in Physiology 5, 68.
Uezumi A, Fukada S, Yamamoto N, Takeda S and Tsuchida K 2010. Mesenchymal progenitors distinct from satellite cells contribute to ectopic fat cell formation in skeletal muscle. Nature Cell Biology 12, 143-152.

Uezumi A, Ito T, Morikawa D, Shimizu N, Yoneda T, Segawa M, Yamaguchi M, Ogawa R, Matev MM, Miyagoe-Suzuki Y, Takeda S, Tsujikawa K, Tsuchida K, Yamamoto $\mathrm{H}$ and Fukada S 2011. Fibrosis and adipogenesis originate from a common mesenchymal progenitor in skeletal muscle. Journal of Cell Science 124, 3654-3664

Urciuolo A, Quarta $M$, Morbidoni V, Gattazzo F, Molon S, Grumati $P$, Montemurro F, Tedesco FS, Blaauw B, Cossu G, Vozzi G, Rando TA and Bonaldo P 2013. Collagen VI regulates satellite cell self-renewal and muscle regeneration. Nature Communications 4, 1964.

Veit G, Kobbe B, Keene DR, Paulsson M, Koch M and Wagener R 2006. Collagen XXVIII, a novel von Willebrand factor A domain-containing protein with many imperfections in the collagenous domain. Journal of Biological Chemistry 281, 3494-3504.

Velleman SG 1999. The role of the extracellular matrix in skeletal muscle development. Poultry Science 78, 778-784.

Velleman SG 2007. Muscle development in the embryo and hatchling. Poultry Science 86, 1050-1054.

Virag JA, Rolle ML, Reece J, Hardouin S, Feigl EO and Murry CE 2007. Fibroblast growth factor-2 regulates myocardial infarct repair: effects on cell proliferation, scar contraction, and ventricular function. American Journal of Pathology 171, 1431-1440.

Voloshenyuk TG, Hart AD, Khoutorova E and Gardner JD 2011. TNF-alpha increases cardiac fibroblast lysyl oxidase expression through TGF-beta and PI3Kinase signaling pathways. Biochemical and Biophysical Research Communications 413, 370-375.

Wang YX, Dumont NA and Rudnicki MA 2014. Muscle stem cells at a glance. Journal of Cell Science 127, 4543-4548.

Wang HT, Liu CF, Tsai TH, Chen YL, Chang HW, Tsai CY, Leu S, Zhen YY, Chai HT, Chung SY, Chua S, Yen CH and Yip HK 2012. Effect of obesity reduction on preservation of heart function and attenuation of left ventricular remodeling, oxidative stress and inflammation in obese mice. Journal of Translational Medicine 10, 145

Woessner JF 1991. Matrix metalloproteinases and their inhibitors in connective tissue remodeling. The FASEB Journal 5, 2145-2154.

Wosczyna MN, Biswas AA, Cogswell CA and Goldhamer DJ 2012. Multipotent progenitors resident in the skeletal muscle interstitium exhibit robust BMPdependent osteogenic activity and mediate heterotopic ossification. Journal of Bone and Mineral Research 27, 1004-1017.

Yamaguchi Y, Mann DM and Ruoslahti E 1990. Negative regulation of transforming growth factor- $\beta$ by the proteoglycan decorin. Nature 346, 281-284.

Yang QY, Liang JF, Rogers CJ, Zhao JX, Zhu MJ and Du M 2013. Maternal obesity induces epigenetic modifications to facilitate zfp423 expression and enhance adipogenic differentiation in fetal mice. Diabetes 62, 3727-3735.

Zhang X, Nestor KE, McFarland DC and Velleman SG 2008. The role of syndecan4 and attached glycosaminoglycan chains on myogenic satellite cell growth. Matrix Biology 27, 619-630.

Zhang X, Liu C, Nestor K, McFarland D and Velleman S 2007. The effect of glypican-1 glycosaminoglycan chains on turkey myogenic satellite cell proliferation, differentiation, and fibroblast growth factor 2 responsiveness. Poultry Science 86, 2020-2028.

Zhao T, Zhao W, Chen Y, Li VS, Meng W and Sun Y 2013. Platelet-derived growth factor-D promotes fibrogenesis of cardiac fibroblasts. American Journal of Physiology - Heart and Circulatory Physiology 304, H1719-H1726.

Zhao X, Wang K, Liao Y, Zeng Q, Li Y, Hu F, Liu Y, Meng K, Qian C, Zhang Q, Guan H, Feng K, Zhou Y, Du Y and Chen Z 2015. MicroRNA-101a inhibits cardiac fibrosis induced by hypoxia via targeting TGFbetaRI on cardiac fibroblasts. Cellular Physiology and Biochemistry 35, 213-226.

Zhou B, Liu Y, Kahn M, Ann DK, Han A, Wang H, Nguyen C, Flodby P, Zhong Q, Krishnaveni MS, Liebler JM, Minoo P, Crandall ED and Borok Z 2012. Interactions between beta-catenin and transforming growth factor-beta signaling pathways mediate epithelial-mesenchymal transition and are dependent on the transcriptional co-activator CAMP-response element-binding protein (CREB)binding protein (CBP). Journal of Biological Chemistry 287, 7026-7038. 